\title{
Molleriella kaputu n. SP. from the West Usambara Mountains, NE Tanzania (Diptera: Chironomidae)
}

\author{
Trond Andersen \\ Department of Natural History, University Museum of Bergen, University of Bergen \\ P.O. Box 7800, NO-5020 Bergen, Norway.E-mail: trond.andersen@um.uib.no
}

\begin{abstract}
The male and female imago of Molleriella kaputu n. sp. are described and figured based on specimens collected in NE Tanzania in 1990. The new species can be separated from M. calcarella Sæther and Ekrem by having a slightly narrower, parallel sided anal point and weaker setae on the inferior volsella, longer $\mathrm{C}$ extension and distinctly shorter tibiae. The specimens were caught in Malaise traps at about $1500 \mathrm{~m}$ altitude in the Mazumbai Forest Reserve in the West Usambara Mountains.
\end{abstract}

\section{Introduction}

The West Usambara Mountains belong to the Eastern Arch, a chain of isolated mountains stretching from the Taita Hills in southern Kenya and the East and West Usambara and Pare mountains in northeastern Tanzania to the Uluguru and Udzungwa mountains in southern Tanzania. These mountains resulted from uplifting and faulting of the main East African plateau and are much older than the East African volcanoes like Mt. Kilimanjaro and Mt. Meru. They are situated close to the Indian Ocean and warm, wet sea air and easterly winds set up a favorable climate. The mountains are covered with forests of different types depending on altitude and rainfall and contain at least 800 endemic plant species. A thorough description of the vegetation was given by Iversen (1991). There are also many endemic animals, thus the mountains are regarded as an important biodiversity hotspot, i.e. an area with a significant reservoir of biodiversity that is under threat from humans.

In the autumn of 1990 the University Museum of Bergen undertook an expedition to the West Usambara Mountains in Tanzania. The fieldwork, which included extensive use of Malaise traps and sweep nets, was mainly conducted in the Mazumbai Forest Reserve in the eastern part of the mountains. Some of the Malaise traps along the Kaputu Stream were run again in the spring and autumn of 1991.

A number of the taxa found in the material were new to science or previously unrecorded from the African continent (see e.g. Andersen and Sæther
1993, 1994a, 1994b; Andersen and Schnell 2000; Sæther and Andersen 1993, 1995; Sæther and Wang 1993a; Stur and Ekrem 2000). Below I describe one of these and place it in the genus Molleriella Sæther and Ekrem. This monotypic genus is based on $M$. calcarella Sæther and Ekrem, a terrestrial species only known to occur in the Netherlands (Sæther and Ekrem 1999).

\section{Material and methods}

The specimens examined were all collected in Malaise traps along the Kaputu Stream and preserved in alcohol. They were later mounted on slides in Canada balsam following the procedure outlined by Sæther (1969). Morphological terminology follows Sæther (1980). Measurements are given as ranges, followed by the mean when four or more specimens have been measured. Coloration descriptions are based on slide mounted specimens.

The holotype and most paratypes are deposited in the Department of Natural History, University Museum of Bergen, Bergen, Norway (ZMBN); some paratypes will be donated to the Zoologische Staatssammlung München, Germany (ZSM).

\section{Molleriella Sather and Ekrem}

Molleriella Sæther and Ekrem, 1999: 162.

Type species: Molleriella calcarella Sæther and Ekrem, 1999: 164.

Other included species: Molleriella kaputu n. sp.

The genus is figured and described in detail based on a few specimens of Molleriella calcarella from the Netherlands (Sæther and Ekrem 1999). They stated that the species has tiny preepisternals. However, on closer examination of the type material no preepisternals could be discerned. But the specimens have a number of distinct, small pits on preepisternum (Figs 1-2). In M. kaputu n. sp. preepisternum also has a few similar pits and thus, these pits probably do not result from damage. Most probably they have a sensory function or represent the opening of glands. However, examination of fresh material is necessary to establish the true nature of these pits. 

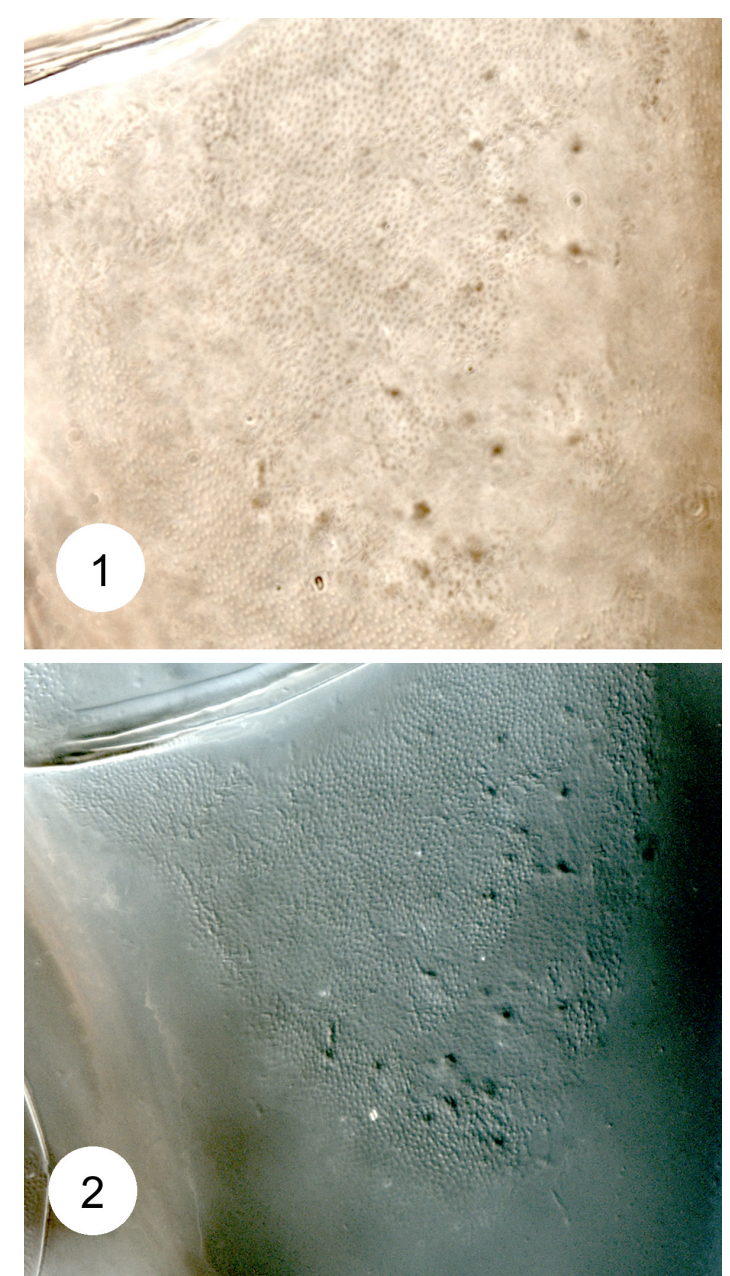

Figures 1-2. Molleriella calcarella Sæther and Ekrem, 1999, holotype. Details of preepisternum showing the distinct, small pits.

The tibial spurs are described as strongly reduced, thin and weak, with at most a couple of basal hairlike denticles on longer spurs. Examination of the types, however, revealed that all tibiae have a spinose apical scale. In M. kaputu n. sp. each leg has a single, long spur and in addition mid and hind tibiae have a single, strong seta at the base of the spur. In M. calcarella there appears to be an additional, shorter spur on all legs.

Sæther and Ekrem (1999) suggested two alternative systematic placements for Molleriella, a relative isolated position either in the Heterotrissocladius group or near Heterotanytarsus Spärck. The spinose scales on all tibiae appear to be unique among Orthocladiinae and most closely resemble the scales found in Xiaomyia Sæther and Wang and Shangomyia Sæther and Wang described from Oriental China (Sæther and Wang 1993b). Sæther and Wang (1993b) placed Xiaomyia and Shangomyia in Chironominae and postulated that they might form the sister group of the tribe Chironomini. However, in a dated molecular phylogeny Cran- ston et al. (2012) suggested a deeper position as the sister to all other Chironominae, thus justifying tribal or possibly subfamily status.

As there can be no doubt of a placement of Molleriella within the subfamily Orthocladiinae, the tibial scales and spurs appear to be an autapomorphy in the genus, representing yet another case of convergent rather than phylogenetically informative evolution in Chironomidae. However, a more detailed interpretation and placement must wait until the larvae and pupae are known and/or fresh material for DNA analyses is collected.

\section{Molleriella kaputu new species}

(Figs 3-17)

Type material: Holotype $\widehat{\delta}$, Tanzania, Tanga Region, West Usambara Mountains, Mazumbai, Kaputu Stream, loc. 10, 1420 m a.s.l., November 1990, Malaise trap, leg. T. Andersen (ZMB's Tanzania Expedition), (ZMBN). Paratypes: 11 ఏ઼ as holotype; 1 q, as holotype except loc. 4, 1680 $\mathrm{m}$ a.s.1.; 2 ठิ $\widehat{0}$ as holotype except loc. 7, $1535 \mathrm{~m}$ a.s.1., 4-10 February 1991; $3 \widehat{\emptyset} \widehat{\jmath}$ as previous except 1-8 August 1991 (ZMBN, ZSM).

Diagnostic characters. The new species is very similar to M. calcarella Sæther and Ekrem in morphological features, but can be distinguished by having slightly more narrow, nearly parallel sided anal point while $M$. calcarella has a wider, slightly spatulate anal point. The new species also has less setae on inferior volsella, the $\mathrm{C}$ extension is longer and the tibiae are distinctly shorter.

Etymology. Named after the type locality, Kaputu Stream. The species epithet is a noun in apposition without any Latin or Latinized elements.

\section{Description}

Male ( $\mathrm{n}=10$, unless stated differently).

Total length 1.70-2.18, $1.90 \mathrm{~mm}$. Wing length 1.01-1.39, $1.15 \mathrm{~mm}$. Total length / wing length 1.57-1.79, 1.65. Wing length / length of fore femur 2.05-2.41, 2.24.

Coloration. Head, thorax and abdomen brown; femur and tibiae lighter brown; wings translucent.

Head (Fig. 3). AR 0.48 (1). Terminal flagellomere 162-205 (2) $\mu \mathrm{m}$ long. Temporal setae 7-12, 9; consisting of 3-6, 4 inner verticals; 1-3, 2 outer verticals and $2-4,3$ postorbitals. Clypeus with $13-$ 23, 17 setae. Tentorium, stipes and cibarial pump as in Figure 4. Tentorium 98-117, $105 \mu \mathrm{m}$ long; 18-22, $19 \mu \mathrm{m}$ wide. Stipes 101-116, $108 \mu \mathrm{m}$ long. Palpomere lengths (in $\mu \mathrm{m}$ ): 22-26, 23; 30-36, 33; 92-104, 98; 108-123, 116 (8); 159 (1). Third 


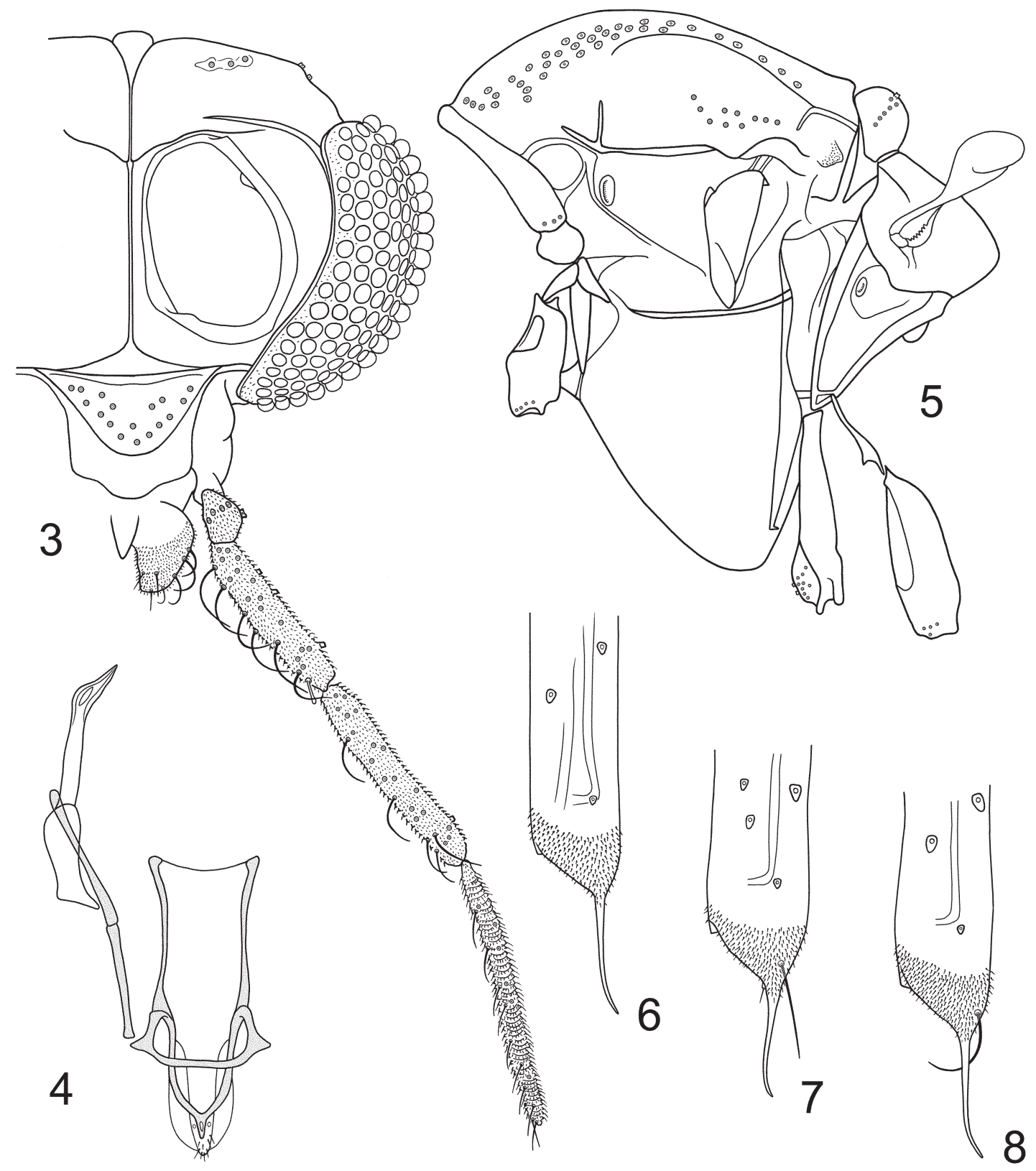

Figures 3-8. Molleriella kaputu n. sp., male. 3, head; 4, tentorium, stipes and cibarial pump; 5, thorax; 6, apex of fore tibia; 7, apex of mid tibia; 8, apex of hind tibia.

palpomere with 1-2 sensilla clavata subapically, longest $11-13 \mu \mathrm{m}$ long.

Thorax (Fig. 5). Antepronotum with 2-4, 3 ventrolateral setae. Dorsocentrals 29-45, 35 starting close to antepronotum; prealars 7-11, 10. Scutellum with 12-16, 14 setae. Preepisternum apparently without minute setae.

Wing (Fig. 11). VR 1.27-1.50, 1.37. C extension 104-128, $116 \mu \mathrm{m}$ long. Brachiolum with 2-3, 3 setae; $C$ extension with about 47-54, 49 non-marginal setae; Sc with about 52-75, 66; R with about
$31-42,36 ; \mathrm{R}_{1}$ with about $22-35,29 ; \mathrm{R}_{4+5}$ with about 33-51, 43; RM with 1-3, 2; $\mathrm{M}$ with about $2-5,3 ; \mathrm{M}_{1+2}$ with about $66-85,74 ; \mathrm{M}_{3+4}$ with about 45-56, 48; $\mathrm{Cu}$ with about 36-47, 41; $\mathrm{Cu}_{1}$ with about 25-34, 29; $\mathrm{PCu}$ with about 74-97, 85; and An with about 47-54, 49 setae. Wing membrane with about 110 setae in cell m; about 600 in $\mathrm{r}_{4+5}$; about 550 in $\mathrm{m}_{1+2}$; about 250 in $\mathrm{m}_{3+4}$; and about 350 in cu and an combined. Squama with 4-8, 6 setae.

Legs. Fore femur 472-568, $508 \mu \mathrm{m}$ long; fore tibia 268-336, $304 \mu \mathrm{m}$ long; mid femur 492-589, 528 $\mu \mathrm{m}$ long; mid tibia 376-452, $404 \mu \mathrm{m}$ long; hind 

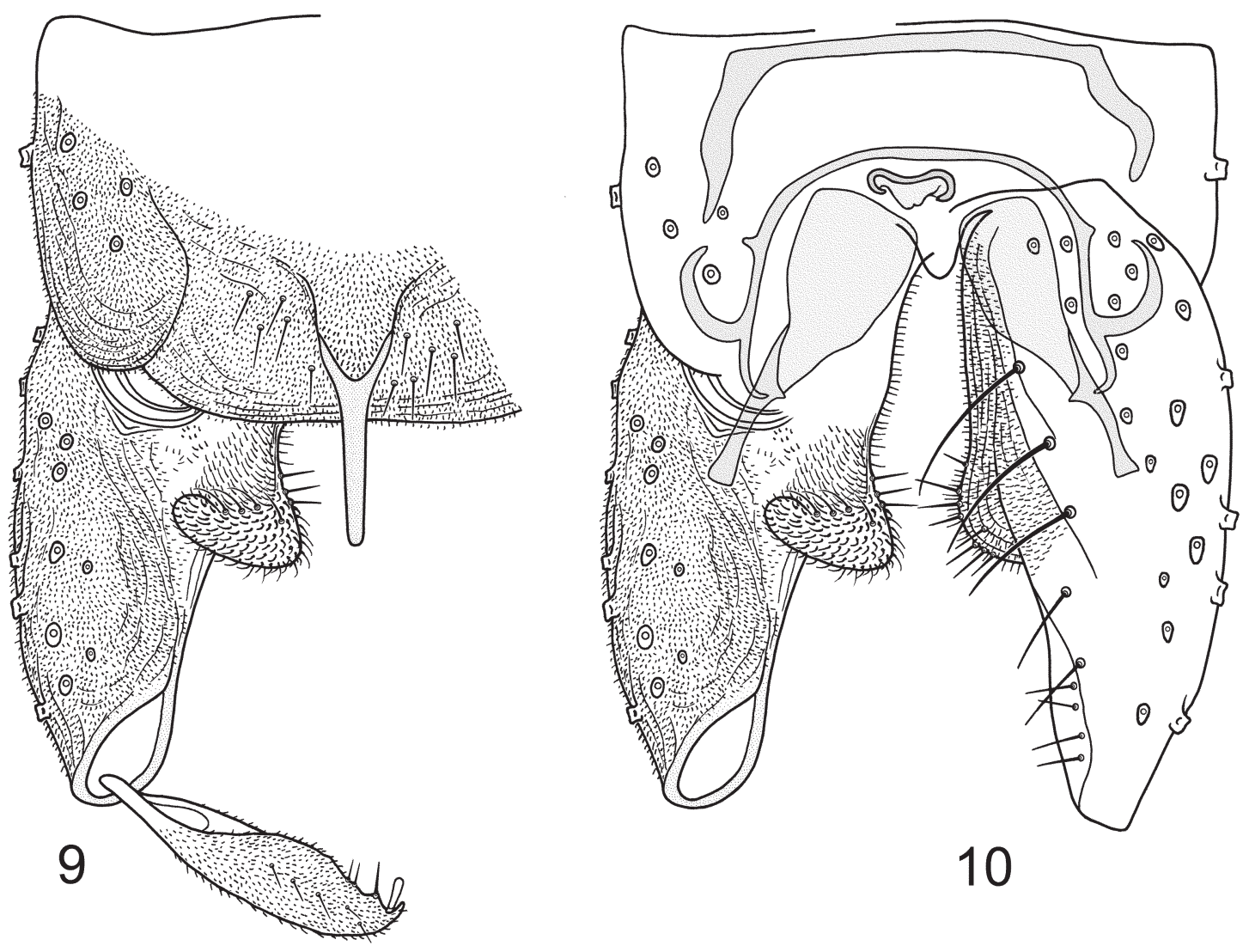

Figures 9-10. Molleriella kaputu n. sp., male. 9, hypopygium, dorsal view; 10, hypopygium with anal point and tergite IX removed, dorsal aspect to the left and ventral aspect to the right.

femur 452-516, $484 \mu \mathrm{m}$ long; hind tibia 436-508, $464 \mu \mathrm{m}$ long; all tarsi lost. Scale of fore tibia (Fig. 6) $42-54,45 \mu \mathrm{m}$ long including $28-35,30 \mu \mathrm{m}$ long spur; scale of mid tibia (Fig. 7) 47-56, $50 \mu \mathrm{m}$ long including 29-36, $33 \mu \mathrm{m}$ long spur; scale of hind tibia (Fig. 8) 50-55, $52 \mu \mathrm{m}$ long including $28-36,32 \mu \mathrm{m}$ long spur. Width at apex of fore tibia $23-28,25 \mu \mathrm{m}$; of mid tibia $29-32,30 \mu \mathrm{m}$; of hind tibia $28-32,30 \mu \mathrm{m}$.

Hypopygium (Figs 9-10). Anal point 33-37, 35 $\mu \mathrm{m}$ long; $6-8,7 \mu \mathrm{m}$ wide at base; $4-6,5 \mu \mathrm{m}$ wide at apex. Tergite IX with altogether 5-11, 8 setae; laterosternite IX with $6-9,7$ setae. Phallapodeme 58-63, $61 \mu \mathrm{m}$ long; transverse sternapodeme 5467, $60 \mu \mathrm{m}$ long. Virga 10-14, $12 \mu \mathrm{m}$ long; 14-18, $16 \mu \mathrm{m}$ wide. Gonocoxite $121-144,130 \mu \mathrm{m}$ long. Superior volsella absent. Inferior volsella 29-35, $31 \mu \mathrm{m}$ long; $22-25,24 \mu \mathrm{m}$ wide at its widest point. Gonostylus 66-76, $68 \mu \mathrm{m}$ long; megaseta 8-10, 9 $\mu \mathrm{m}$ long. HR 1.76-1.98, 1.87. HV 2.64-2.96, 2.78.

Female $(\mathrm{n}=1)$.

Total length $1.25 \mathrm{~mm}$. Wing length $0.96 \mathrm{~mm}$. Total length / wing length 1.30. Wing length / length of fore femur 2.85 .

Coloration. Head, thorax and abdomen brown; femur and tibiae lighter brown; wings translucent.

Head. Antenna missing. Temporal setae 11, consisting of 5 inner verticals; 2 outer verticals and 4 postorbitals. Clypeus with 21 setae. Tentorium $72 \mu \mathrm{m}$ long, $8 \mu \mathrm{m}$ wide. Stipes $90 \mu \mathrm{m}$ long. Palp segment lengths (in $\mu \mathrm{m}$ ): $22,26,75,95$, fifth palpomere missing. Third palpomere with 2 sensilla clavata subapically, longest $19 \mu \mathrm{m}$ long.

Thorax. Antepronotum with 3 ventrolateral setae. Dorsocentrals 47 starting close to antepronotum; prealars 9. Scutellum with 14 setae.

Wing (Fig. 12). VR 1.37. C extension $173 \mu \mathrm{m}$ long. Brachiolum with 2 setae; $\mathrm{C}$ extension with about 86 non-marginal setae; Sc with about 27; R with about 24; $\mathrm{R}_{1}$ with about $22 ; \mathrm{R}_{4+5}$ with about 41 ; RM with 2; M with 2; $\mathrm{M}_{1+2}$ with about $56 ; \mathrm{M}_{3+4}$ with about $45 ; \mathrm{Cu}$ with about $25 ; \mathrm{Cu}_{1}$ with about 23; $\mathrm{PCu}$ with about 49; and An with about 29 setae. Wing membrane with about 60 setae in cell $\mathrm{m}$;

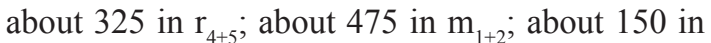




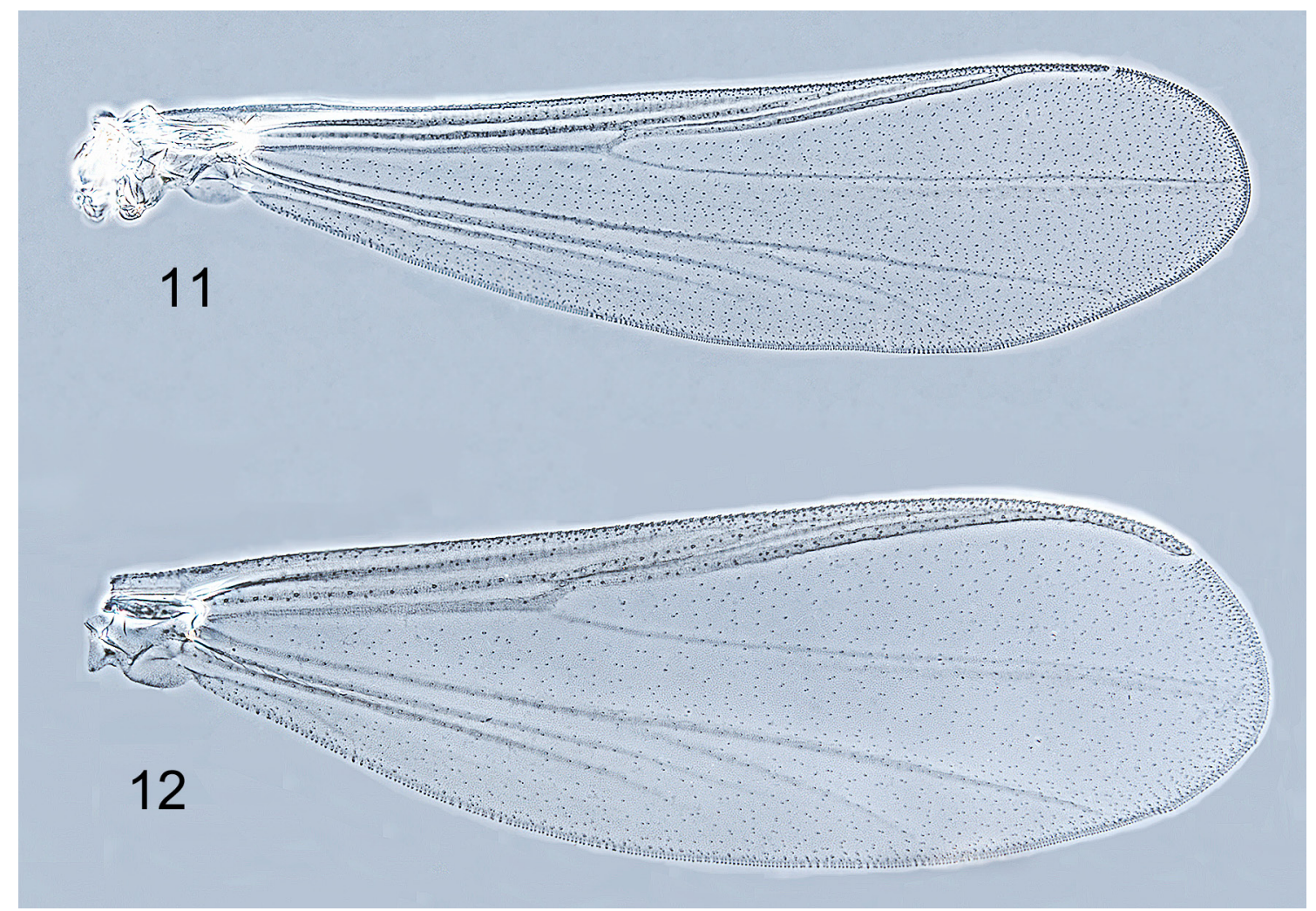

Figures 11-12. Molleriella kaputu n. sp., 11, wing, male; 12, wing, female.

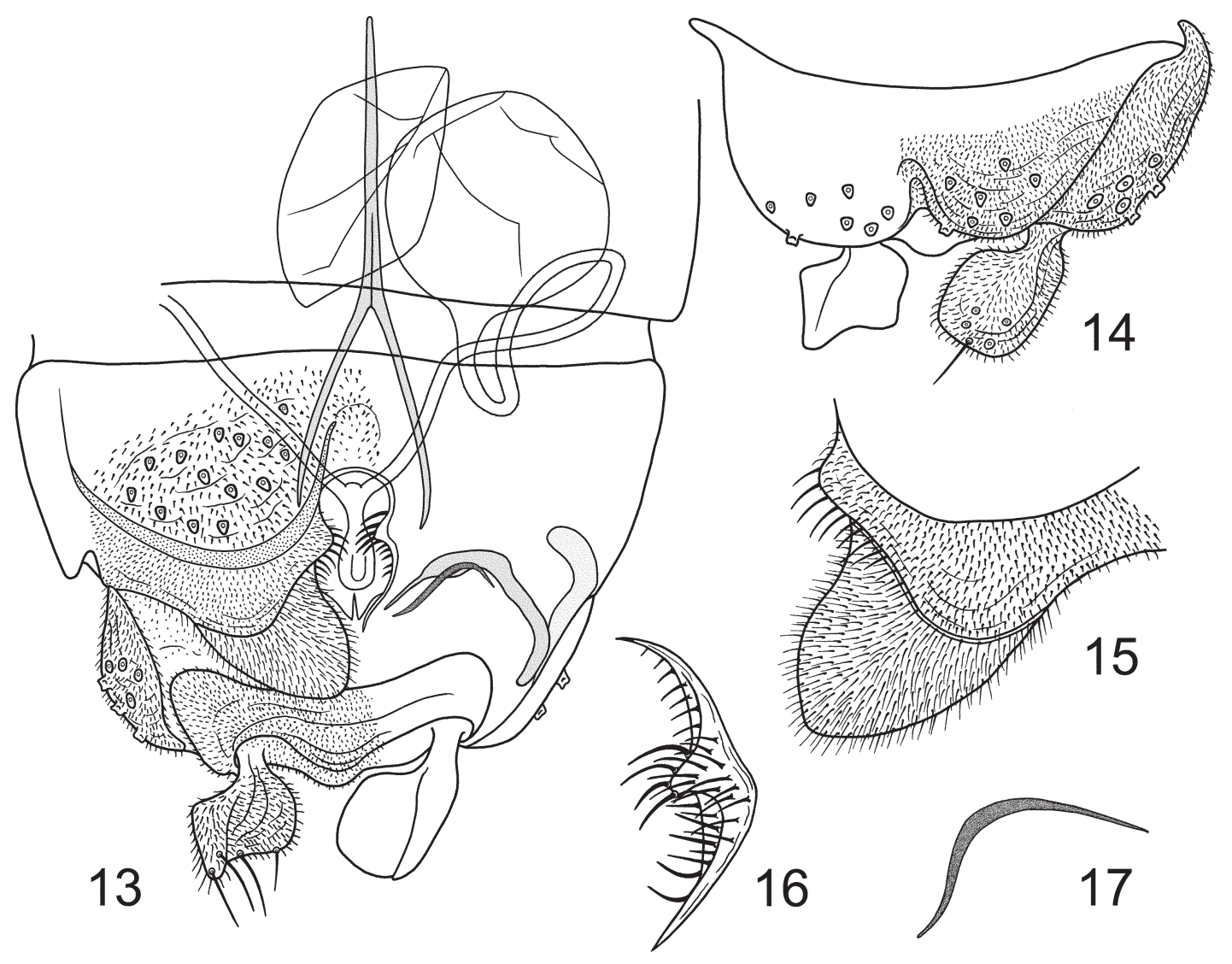

Figures 13-17. Molleriella kaputu n. sp., female. 13, genitalia, ventral view; 14, genitalia, dorsal view; 15, ventrolateral lobe; 16, dorsomesal lobe; 17, apodeme lobe. 
$\mathrm{m}_{3+4}$; and about 250 in $\mathrm{cu}$ and an combined. Squama with 5 setae.

Legs. Fore femur $380 \mu \mathrm{m}$ long; fore tibia $284 \mu \mathrm{m}$ long; mid femur $420 \mu \mathrm{m}$ long; mid tibia $344 \mu \mathrm{m}$ long; hind femur $404 \mu \mathrm{m}$ long; hind tibia $396 \mu \mathrm{m}$ long; all tarsi lost. Scale of fore tibia $39 \mu \mathrm{m}$ long including $26 \mu \mathrm{m}$ long spur; scale of mid tibia 40 $\mu \mathrm{m}$ long including $26 \mu \mathrm{m}$ long spur; scale of hind tibia $48 \mu \mathrm{m}$ long including $30 \mu \mathrm{m}$ long spur. Width at apex of fore tibia $28 \mu \mathrm{m}$; of mid tibia $30 \mu \mathrm{m}$; of hind tibia $31 \mu \mathrm{m}$.

Genitalia (Figs 13-17). Gonocoxite IX with 6 setae. Tergite IX with posteromedial deep incision, each side with $7-8$ setae. Cercus $47 \mu \mathrm{m}$ long. Seminal capsules distorted in the single specimen, about $76 \mu \mathrm{m}$ long, $62 \mu \mathrm{m}$ wide, with $11 \mu \mathrm{m}$ long neck. Notum $72 \mu \mathrm{m}$ long. Ventrolateral lobe bluntly triangular, $52 \mu \mathrm{m}$ long, $48 \mu \mathrm{m}$ wide at its widest point, covered with microtrichia. Dorsomesal lobe narrow, $46 \mu \mathrm{m}$ long, $8 \mu \mathrm{m}$ wide.

Pupa and larva. Unknown.

\section{Remarks}

The new species is very similar to Molleriella calcarella in most morphological features, and the two species also overlap in most measurements. However, the male $M$. calcarella has a spatulate anal point, while the anal point in $M$. kaputu is slightly narrower and nearly parallel sided. $M$. calcarella apparently also has more and stronger setae on the inferior volsella than $M$. kaputu. In $M$. calcarella the $\mathrm{C}$ extension is $79-83 \mu \mathrm{m}$ long in the male and on average $121 \mu \mathrm{m}$ long in the female, while in $M$. kaputu it is on average $116 \mu \mathrm{m}$ long in the male and $173 \mu \mathrm{m}$ long in the female. The most distinct difference seems however, to be in the length of the tibiae; in $M$. calcarella fore tibia is $430-435 \mu \mathrm{m}$ long in the male and on average $361 \mu \mathrm{m}$ in the female, while in M. kaputu it is on average $304 \mu \mathrm{m}$ long in the male, $284 \mu \mathrm{m}$ long in the female. Using an unconventional leg ratio, length of tibia / length of femur, the fore leg ratio is 0.81 in male M. calcarella and $0.54-0.62,0.58$ in male M. kaputu, $0.85-0.88,0.87$ in female $M$. calcarella and 0.75 in female M. kaputu.

\section{Habitat}

Two main vegetation types are found in the Mazumbai Forest Reserve: intermediate forest and mountain rainforest. At higher elevations outside the forest reserve dry montane forest occurs. The trees in the intermediate forest can reach a height of $50 \mathrm{~m}$, while those at higher altitudes are reduced in height with increasing altitude.

During our stay at Mazumbai in late autumn 1990 daily maximum temperatures ranged from 17.5 to $23.0^{\circ} \mathrm{C}$ and the minima from 15.0 to $20.5^{\circ} \mathrm{C}$. In the Usambara mountains there are two main rainy seasons, a heavier one from the beginning of March

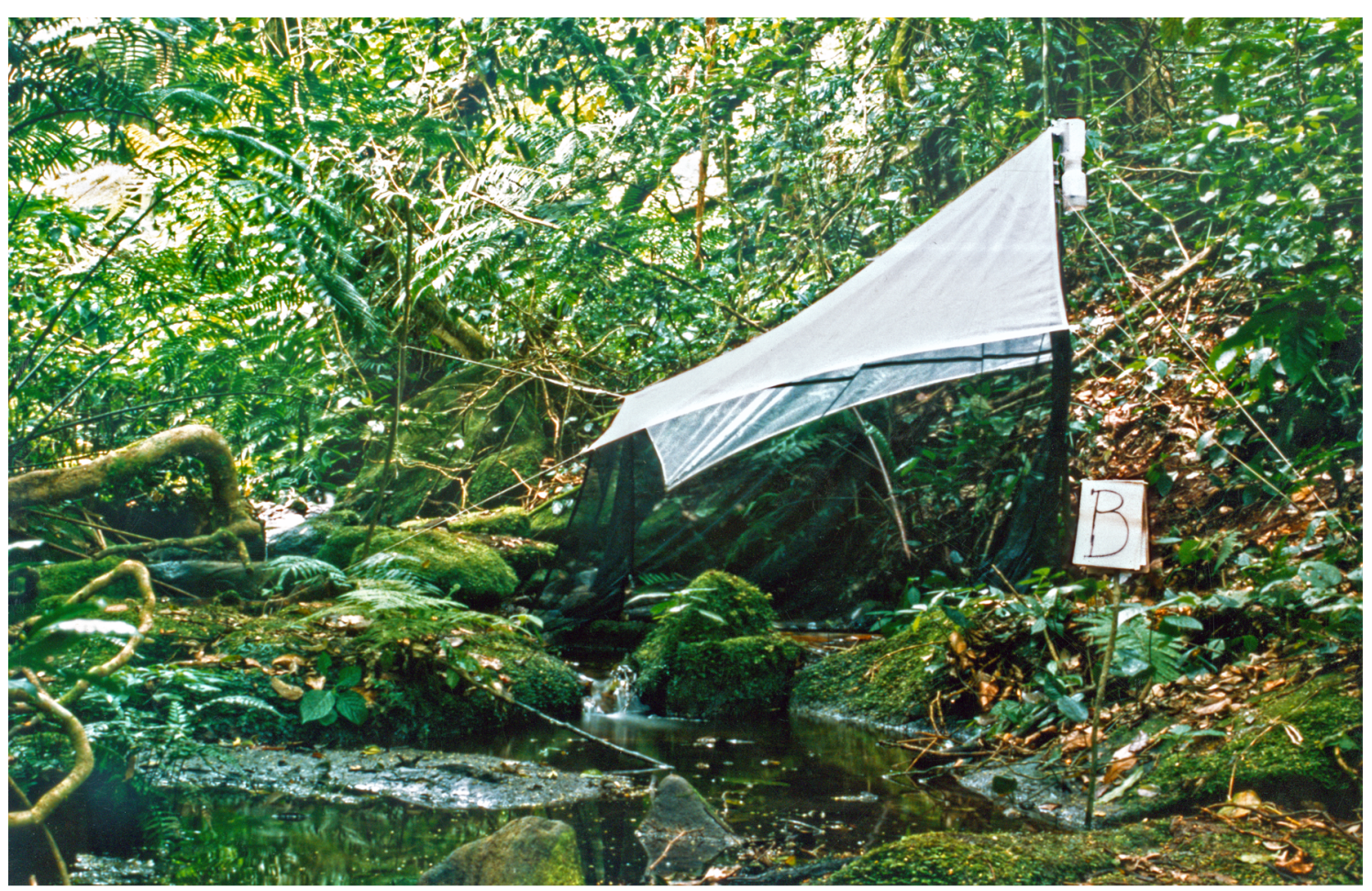

Figure 18. Kaputu Stream at locality 7 at $1535 \mathrm{~m}$ altitude. The Malaise trap was placed across the stream. 
to the end of May, and a lighter one in September and October. Mean annual rainfall at Mazumbai (1945-1975) was $1138 \mathrm{~mm}$.

The Kaputu Stream is located on the eastern side of Kwagoroto Hill and is surrounded by nearly undisturbed rainforest. It originates at about $1860 \mathrm{~m}$ altitude and runs down to a marshy area at about $1400 \mathrm{~m}$ altitude. Four relatively large waterfalls are located along the stream, but in most stretches the water speed is moderate. The water temperatures measured varied between 14.6 and $17.6^{\circ} \mathrm{C}$ and the $\mathrm{pH}$ was 5.9.

The specimens of $M$. kaputu were collected at three of the Malaise trap localities along the Kaputu Stream described in Andersen and Johanson (1993). At locality 4, at $1680 \mathrm{~m}$ altitude, the stream was 1-3 $\mathrm{m}$ wide and 3-15 cm deep and the current was moderate; the substrate was mostly sand, gravel and stones densely covered with moss. At locality 7 (Fig. 18), at $1535 \mathrm{~m}$ altitude, the stream was 2-3 $\mathrm{m}$ wide and 5-15 cm deep and the current was rather slow; the substrate was mostly gravel and stones densely covered with moss, with some mud in the backwaters. At locality 10, at $1420 \mathrm{~m}$ altitude, the stream was 0.5-2 m wide and 10-20 $\mathrm{cm}$ deep and the current was moderate; the substrate was mostly fine sand, mud and some larger stones densely covered with moss.

According to Sæther and Ekrem (1999) M. calcarella is terrestrial; it was caught in "mini-traps" placed on the banks of a small lake about one meter from the water edge. As the material of $M$. $\mathrm{ka}$ putu was collected in Malaise traps, this species too might well be terrestrial, having originated in the moss or wet soil along the Kaputu Stream.

\section{Acknowledgements}

I am greatly indebted to Paddy Ashe, Dublin, Torbjørn Ekrem, Trondheim and Martin Spies, München and two anonymous reviewers for comments and corrections to the manuscript. Geir Søli, Oslo and Kjell Arne Johanson, Stockholm participated in the expedition to the Usambara Mountains in 1990. Gladys Ramirez made the slide preparations.

\section{References}

Andersen, T. and Johanson, K.A. 1993. Caddis flies (Trichoptera) from a mountain rain forest in NE Tanzania. In Otto, C. (Ed.), Proceedings of the 7th International Symposium on Trichoptera. Backhuys Publishers, Leiden, pp. 59-64.

Andersen, T. and Sæther, O.A. 1993. Lerheimia, a new genus of Orthocladiinae from Africa (Dip- tera, Chironomidae). - Spixiana 16: 105-122.

Andersen, T. and Sæther, O.A. 1994a. Colosmittia clavata gen. n., sp. n., a new orthoclad from the West Usambara Mountains, Tanzania (Diptera: Chironomidae). - Journal of the Kansas Entomological Society 66: 439-443.

Andersen, T. and Sæther, O.A. 1994b. Usambaromyia nigrala gen. n., sp. n., and Usambaromyiinae, a new subfamily among the Chironomidae (Diptera). - Aquatic Insects 16: 21-29.

Andersen, T. and Schnell, Ø.A. 2000. New species of Bryophaenocladius Thienemann, 1934 from Tanzania, with bare squama (Diptera: Chironomidae). - Aquatic Insects 22: 48-57.

Cranston, P.S., Hardy, N.B. and Morse, G.E. 2012. A dated molecular phylogeny for the Chironomidae (Diptera). - Systematic Entomology 37: 172-188.

Iversen, S.T. 1991. The Usambara Mountains, NE Tanzania: phytogeography of vascular plant flora. - Acta Universitatis Upsaliensis Symbolae Botanicae Upsalienses 29(3): 1-234.

Sæther, O.A. 1969. Some Nearctic Podonominae, Diamesinae, and Orthocladiinae (Diptera: Chironomidae). - Bulletin of the Fisheries Research Board of Canada 170: 1-154.

Sæther, O.A. 1977. Female genitalia in Chironomidae and other Nematocera: morphology, phylogenies, keys. - Bulletin of the Fisheries Research Board of Canada 197: 1-209.

Sæther, O.A. 1980. Glossary of chironomid morphology terminology (Diptera: Chironomidae). - Entomologica scandinavica, Supplement 14: $1-51$.

Sæther, O.A. and Andersen, T. 1993. Lobosmittia, a new genus of orthoclads from Tanzania and Turkey (Diptera: Chironomidae). - Tijdschrift voor Entomologie 136: 283-287.

Sæther, O.A. and Andersen, T. 1995. Ionthosmittia caudiga n. gen. n. sp., a new orthoclad from the Usambara Mts, Tanzania (Diptera Chironomidae). - Tropical Zoology 8: 197-202.

Sæther, O.A. and Ekrem, T. 1999. Molleriella, a new terrestrial orthoclad genus from the Netherlands (Diptera: Chironomidae). - Acta Zoologica Academiae Scientiarum Hungaricae 45: 161-168.

Sæther, O.A. and Wang, X. 1993a. Euryhapsis fuscipropes sp. n. from China and Tokyobrillia anderseni sp. n. from Tanzania, with a review 
of genera near Irisobrillia Oliver (Diptera: Chironomidae). - Annales de Limnologie 28: 209-223.

Sæther, O.A. and Wang, X. 1993b. Xiaomyia, Shangomyia and Zhouomyia, three new and unusual genera of Chironomini from Oriental China (Diptera: Chironomidae). - Entomologica scandinavica 24: 185-195.

Stur, E. and Ekrem, T. 2000. Tanytarsus usambarae, spec. nov. from West Usambara Mts., Tanzania, East Africa (Insecta, Diptera, Chironomidae). - Spixiana 23: 219-223.

Article submitted 17. June 2014, accepted 29. November 2014, published 22. December 2014. 